\title{
Food Waste Management Using the Hermetia Illucens Insect
}

\author{
Wojciech Czekałai, Damian Janczak', Marta Cieślik², \\ Jakub Mazurkiewicz', Jakub Pulka' \\ 1 Institute of Biosystems Engineering, Poznań University of Life Sciences, Wojska Polskiego 50, 60-627, Poznań, \\ Poland \\ 2 Department of Biotechnology and Food Microbiology, Poznań University of Life Sciences, Wojska Polskiego \\ 48, 60-637 Poznań, Poland \\ * Corresponding author's e-mail: wojciech.czekala@up.poznan.pl
}

\begin{abstract}
In modern agricultural biogas plants, the biowastes are being increasingly used for the biogas production. The food waste is also widely used in larvae breeding. This is an important because, based on biowaste, its proper management and green energy production is possible. This study aims to determine the biogas and methane efficiency of the Hermetia illucens larvae that were fed using the food waste. In the research on the biogas and methane efficiency, the Hermetia illucens larvae were used. The total solids (TS) of the substrate equals $30.35 \%$, and the volatile solids (VS) content was $92.31 \%$ of TS. The larvae were fed only with the food waste of plant origin. The obtained substrates were homogeneous. The experiment was carried out under mesophilic anaerobic digestion conditions $-39^{\circ} \mathrm{C}$ in the 21 -chamber biofermentor set in the Institute of Biosystems Engineering in Poznan University of Life Sciences. The anaerobic digestion process in the batch reactor ran correctly. Fermentation inhibition was not detected. The biogas efficiency for larvae amounted to $198.75 \mathrm{~m}^{3} \cdot \mathrm{Mg}^{-1}$ fresh mass (FM). On the other hand, the methane efficiency, amounted to $127.73 \mathrm{~m}^{3} \cdot \mathrm{Mg}^{-1}$, at the methane concentration of $64.27 \%$. On the basis of the research, it was found that the larvae feeding on food waste can be used directly as anaerobic digestion in the bioconversion process.
\end{abstract}

Keywords: waste management, food waste, environmental protection, circular economy, Hermetia illucens

\section{INTRODUCTION}

Sustainable management of agricultural products and food industry waste is one of the greatest challenges of the $21^{\text {st }}$ century. It is estimated that over $30 \%$ of food is not consumed. The waste can have a negative impact on the environment (Ferronato and Torretta, 2019; Obidzinski et al., 2019). This problem concerns practically all countries in the world. On the other hand, most of the generated food waste can be managed with benefits (Filho and Kovaleva, 2015; Moustakas and Loizidou, 2018).

The biological waste processes are an increasingly popular solution in waste management (Wolna-Maruwka and Dach, 2009; Piotrowska-Cyplik et al. 2013). This is due to the fact that it fits into the ideas of circular economy
(Czekała et al., 2020). Composting is one of the biological processes (Cerda et al., 2018; Nalepa et al., 2018), just like the biogas production in the anaerobic digestion process (Mustafa et al., 2016). The composting process takes place under the aerobic conditions and is popular in the management of many substrates (Czekała et al., 2018; Żukowska et al., 2019). Building a composting plant is cheaper and easier to run than in the case of an agricultural biogas plant. Despite this, biogas plants are becoming an increasingly popular alternative to composting. When effective technology is used, it is possible to change the composition of the substrates gradually. This should be considered a great advantage because the substrates that can be used for biogas production are large (Wandera et al., 2018; Koryś et al., 2019). Another undoubted 
advantage of a biogas plant is the possibility of energy recovery as part of the biogas or electricity and heat production using a cogeneration process (Mazurkiewicz et al., 2019).

The crucial activity allowing the proper functioning of a biogas plant is ensuring the daily supplies of substrates and its composition. As a result, the process will be able to run correctly, and energy production will be more stable. The possibility of using waste to produce the agricultural biogas has been recognized in many studies, both our own (Janczak et al., 2016; Kozłowski et al., 2019) and by other authors (Soundararaj Manju and Senophiyah-Mary, 2020). For the biogas production, agricultural biogas plants also utilize wasted food of plant origin, including, i.e., selectively collected unsold vegetables and fruits, market waste, or household residues (Czekała et al., 2016). Another important aspect of energy production is the management of the waste after the biogas production. This substance can be successfully used in the energy processes (Czekała, 2019), directly as a fertilizer (Robles-Aguilar et al., 2019), or as a substrate for the production of compost. It has been reported that the use of digestate, in addition to providing nutrients to plants, also plays an important role in the inhibiting plant (fungal and bacterial) and insect pathogens (Lu et al., 2019).

One of the attractive food waste treatment techniques is the bioconversion method (Kiran et al., 2014). In the sense of the bioconversion principles, waste can be processed using living organisms such as insects. The use of insect larvae for waste processing can be mentionedas an example of an alternative solution that allows the simultaneous management of waste and energy production(Diener et al., 2011; Čičková et al., 2015). An example would be Hermetia illucens (Black soldier fly) larvae. These larvae are characterized by a rapid biomass growth as well as high protein and fat content in dry matter (Czekała, 2017, Kierończyk et al., 2019).

The study aimsat determining the biogas and methane efficiency of Hermetia illucens larvae that were fed food waste. The scope of the work included obtaining the food waste of plant origin, obtaining Hermetia illucens larvae, investigation of the biogas, and methane efficiency.

\section{MATERIALS AND METHODS}

\section{Description of the materials}

The Hermetia illucens larvae fed on food waste were the subject of the study. The larvae were fed only with the food waste of plant origin. The total solids of waste used for research was about $10 \%$, and the content of volatile solids was over $90 \%$. The obtained waste were homogeneous and without any pollution. The total solid of the Hermetia illucens larvae was $30.35 \%$, and the organic matter content was $92.31 \%$ in total solids.

\section{Biogas production system}

The experiment was carried under mesophilic anaerobic digestion conditions $\left(39^{\circ} \mathrm{C}\right)$ in the 21-chamber biofermentor set at the Ecotechnologies Laboratory of the Institute of Biosystems Engineering at Poznań University of Life Sciences (Figure 1).

The anaerobic digestion experiments were carried out in the glass tank reactors. The inoculum was the digestate liquid fraction from one of the Polish biogas plants. The volume of biogas and its qualitative composition were checked using the GA5000 GeoTech company.

The biogas and methane efficiency were tested according to the German standard DIN 38414/S8 and VDI 4630. The methodology has been described in detail in the work (Cieslik et al., 2016).

\section{RESULTS AND DISCUSSION}

The Hermetia illucens larvae were processed in the anaerobic digestion. The fermentation of the substrate in the absence of oxygen took 29 days and was stable. The results of the biogas and methane efficiency calculated on fresh mass, total solids, volatile solids, and additionally, the concentration of methane in biogas were presented in Table 1.

The anaerobic digestion process in the batch reactor ran correctly. The fermentation inhibition was not detected. The energy potential of the substrate calculated on fresh mass was high. The biogas efficiency for larvae amounted to $198.75 \mathrm{~m}^{3} \cdot \mathrm{Mg}^{-1}$ in fresh mass. On the other hand, the methane efficiency, amounted to $127.73 \mathrm{~m}^{3} \cdot \mathrm{Mg}^{-1}$. The results on total solids were 


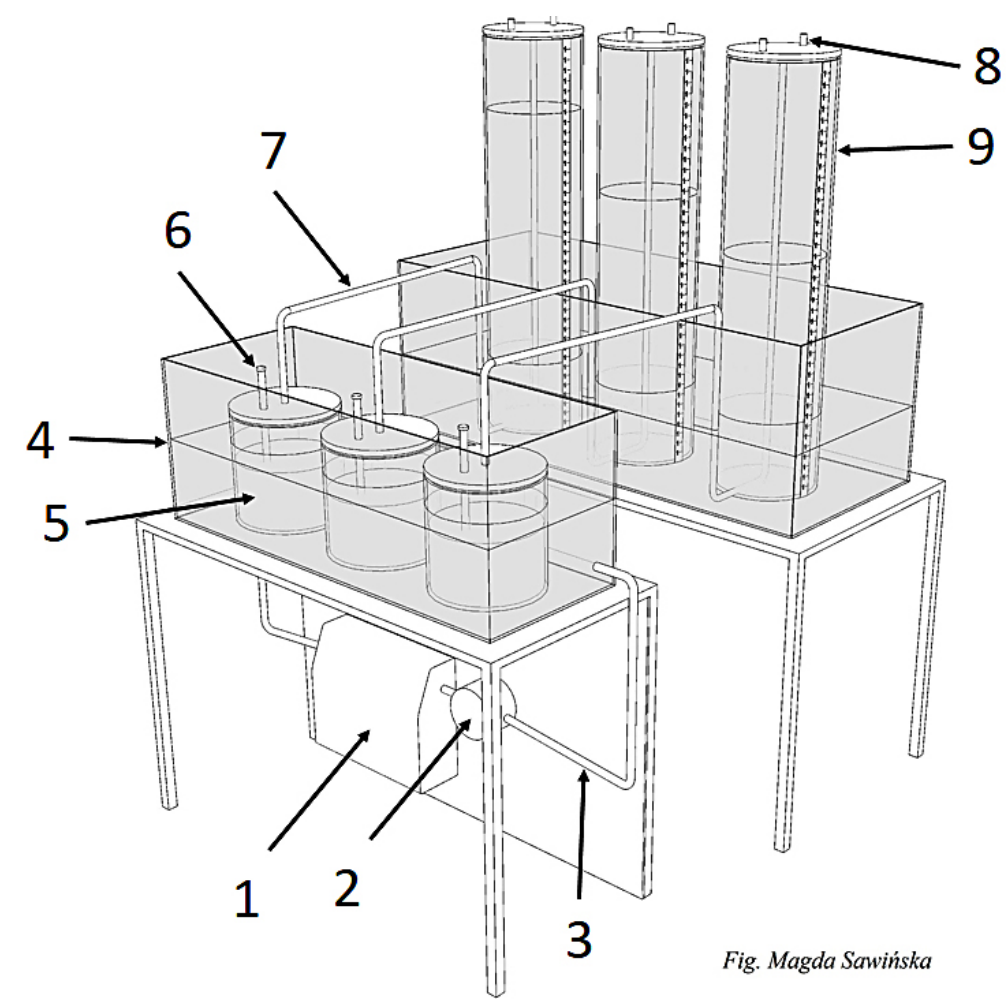

Fig. 1. The scheme of the biofermentor for the biogas production research 3 -chamber section $(1-$ water heater with temperature regulator, 2 - water pump, 3 - insulated conductors of calefaction liquid, 4 - water coat with temp. $39^{\circ} \mathrm{C}, 5$ - biofermentor with charge capacity $2 \mathrm{dm}^{3}, 6$ - sampling tubes, 7 - biogas transporting tube, 8 - gas sampling valve, 9 - biogas volume-scale reservoir).

$654.72 \mathrm{~m}^{3} \cdot \mathrm{Mg}^{-1}$ for biogas and $420.81 \mathrm{~m}^{3} \cdot \mathrm{Mg}^{-1}$ for methane. These values should be considered as high, compared to other biogas substrates, for example, food waste. The methane content in biogas during the experiment was $64.27 \%$, which also should be considered as a good result.

As mentioned in the Introduction chapter, many substrates can be used for biogas production. Despite this, other substrates and innovative technologies that can be used in these installations are desirable. The primary aim is improving the balance of the biogas plant operations.

Protecting human health and ensuring appropriate conditions in the environment are some of the most important challenges. Therefore, the problem of using food waste for the energy production using the bioconversion methods should also take into account the environmental aspects. The use of Hermetia illucens or other insects fed on waste can significantly help solve many environmental problems. This applies especially to the management of insects and the production of components for the production of feed or food. This is directly related to the increasing amount of generated waste, with limited the areas for growing food at the same time. The production of energy from renewable sources is also an important issue. The production of biofuels, especially agricultural biogas, is much more beneficial to the environment than the production of energy from fossil fuels. It is worth noting that a wide spectrum of waste can be used for the production of agricultural biogas, which is another advantage in favor of choosing this method.

The management of waste for energy production, including the bioconversion process, is directly connected to the circular economy. Therefore, this method should be further developed

Table 1. Cumulative biogas and methane production for Hermetia illucens larvae [FM - fresh mass, TS - total solids, VS - Volatile solids, MC - methane content]

\begin{tabular}{|c|c|c|c|c|c|c|c|}
\hline \multirow{2}{*}{ Sample } & \multicolumn{6}{|c|}{ Cumulative biogas production $(\mathrm{CBP})\left[\mathrm{m}^{3} \cdot \mathrm{Mg}^{-1}\right]$} & \multicolumn{3}{c|}{ Cumulative methane production $(\mathrm{CMP})\left[\mathrm{m}^{3} \cdot \mathrm{Mg}^{-1}\right]$} & \multirow{2}{*}{$\mathrm{MC}[\%]$} \\
\cline { 2 - 7 } & $\mathrm{FM}$ & TS & VS & FM & TS & VS & \\
\hline Larvae & 198.75 & 654.72 & 709.33 & 127.73 & 420.81 & 455.87 & 64.27 \\
\hline
\end{tabular}


and improved. Biogas plants are installations that can operate in any commune, regardless of the weather conditions, with high efficiency reaching even above $90 \%$. Therefore, they are an excellent alternative to other renewable energy sources, e.g., wind farms.

\section{CONCLUSION}

The increasingly severe environmental problems and stringent legal regulations are the reason for the growing interest in the topic of waste management. New solutions that will allow managing a lot of waste in a way that is least harmful to the environment, are expected.

Agricultural biogas plants are places where the waste can be processed. The food waste can be used directly as a fermentation substrate or in the bioconversion process. Using the food waste and agri-food by-products from the food processing industry to increase the growth of insects for energy purposes seems to be a rational solution. One of the innovative solutions allowing for the production of biogas and then energy may be the use of the Hermetia illucens insect larvae. The results show that larvae feeding on the waste of plant origin can be used for biogas production. This confirmed the results obtained as part of the experiment.

The presented solution is an alternative to anaerobic digestion of food waste without any treatments. Regardless of whether biogas will be produced from waste or larvae, it will be included in the renewable energy sources. According to the authors, the bioconversion research should be continued. This particularly applies to the selection of substrates that are sources of energy production directly, and those that were previously food for larvae.

\section{Acknowledgements}

This study was performed in the framework of the IN OIL project: An innovative method for bioconversion of by-products from food processing industry that was financed by the National Centre for Research and Development within the LiderVII Programme LIDER/5/0148/L-7/15/NCBR/2016.

Publication is funded by the Polish National Agency for Academic Exchange under the International Academic Partnerships Programme from the project ,, Organization of the 9th International
Scientific and Technical Conference entitled Environmental Engineering, Photogrammetry, Geoinformatics - Modern Technologies and Development Perspectives".

\section{REFERENCES}

1. Cerda A., Artola A., Font X., Barrena R., Gea T., Sánchez A., 2018. Composting of food wastes: Status and challenges. Bioresource Technology 248, Part A, 57-67. https://doi.org/10.1016/j. biortech.2017.06.133

2. Čičková H., Newton L., Lacy R.C., Kozánek M. 2015. The use of fly larvae for organic waste treatment. Waste Management 35, 68-80. https://doi. org/10.1016/j.wasman.2014.09.026

3. Cieślik M., Dach J., Lewicki A., Smurzyńska A., Janczak D., Pawlicka-Kaczorowska J., Boniecki P., Cyplik P., Czekała W., Jóźwiakowski K. 2016. Methane fermentation of the maize straw silage under meso- and thermophilic conditions. Energy 115(2), 1495-1502. https://doi.org/10.1016/j. energy.2016.06.070

4. Czekała W., Smurzyńska A., Cieślik M., Boniecki P., Kozłowski K. 2016. Biogas efficiency of selected fresh fruit covered by the Russian embargo. Energy And Clean Technologies Conference Proceedings, SGEM 2016, VOL III: 227-233. doi:10.5593/ sgem2016HB43

5. Czekała W. Concept of IN-OIL project based on bioconversion of by-products from food processing industry. 2017. Journal of Ecological Engineering 18(5), 180-185. DOI: https://doi. org/10.12911/22998993/76211

6. Czekała W., Dach J., Przybył J., Mazurkiewicz J., Janczak D., Lewicki A., Smurzyńska A., Kozłowsk K. 2018. Composting of sewage sludge with solid fraction of digested pulp from agricultural biogas plant. E3S Web of Conferences 30, 02001 (2018) Water, Wastewater and Energy in Smart Cities. https://doi.org/10.1051/e3sconf/20183002001

7. Czekała W. 2019. Biogas Production from Raw Digestate and its Fraction. Journal of Ecological Engineering20(6), 97-102. https://doi. org/10.12911/22998993/108653

8. Czekała W., Lewicki A., Pochwatka P., Czekała A., Wojcieszak D., Jóźwiakowski K., Waliszewska H. 2020. Digestate management in polish farms as an element of the nutrient cycle. Journal of Cleaner Production 242, 118454. https://doi.org/10.1016/j. jclepro.2019.118454

9. Diener S., Studt Solano N.M., Gutiérrez F.R., Zurbrügg C., TocknerK. 2011. Biological Treatment of Municipal Organic Waste using Black Soldier Fly Larvae. Waste and Biomass Valorization 2, 357-363. 
https://doi.org/10.1007/s12649-011-9079-1

10. Ferronato N., Torretta V. 2019. Waste Mismanagement in Developing Countries: A Review of Global Issues. International Journal of Environmental Research and Public Health 16(6), 1-28. doi: 10.3390/ ijerph16061060.

11. Filho W.L., Kovaleva M. 2015. Food Waste and Sustainable Food Waste Management in the Baltic Sea Region. Springer International Publishing Switzerland 2015. Print ISBN

12.978-3-319-10905-3. https://doi. org/10.1007/978-3-319-10906-0

13. Janczak D.,Kozłowski., Zbytek Z., Cieślik M., Bugała A., Czekała A. 2016. Energetic Efficiency of the Vegetable Waste Used as Substrate for Biogas Production. 2nd international conference on chemical materials and process (ICCMP 2016); volume 64. doi: 10.1051/matecconf/20166406002

14. Kierończyk B., Sypniewski J., Rawski M., Czekała W., Świątkiewicz S., Józefiak D. From waste to sustainable feed material: the effect of Hermetia illucens oil on the growth performance, nutrient digestibility, and gastrointestinal tract morphometry of broiler chickens. Annals of Animal Science. DOI: 10.2478/aoas-2019-0066. Ahead of Print

15. Kiran E.U., Trzcinski A.P., Ng W.J., Liu Y. 2014. Bioconversion of food waste to energy: A review. Fuel 134, 389-399. https://doi.org/10.1016/j. fuel.2014.05.074

16. Koryś K.A., Latawiec A.E., Grotkiewicz K., Kuboń M. 2019. The Review of Biomass Potential for Agricultural Biogas Production in Poland. Sustainability 11, 6515; doi:10.3390/su11226515

17. Kozłowski K., Pietrzykowski M., Czekała W., Dach J., Kowalczyk-Juśko A., Jóźwiakowski K., Brzoski M. 2019. Energetic and economic analysis of biogas plant with using the dairy industry waste. Energy 183, 15, 1023-1031. https://doi.org/10.1016/j. energy.2019.06.179

18. LuJ., Muhmood A., Czekała W., Mazurkiewicz J., Dach J., Dong R. 2019. Untargeted Metabolite Profiling for Screening Bioactive Compounds in Digestate of Manure under Anaerobic Digestion. Water 11, 2420; https://doi.org/10.3390/w11112420

19. Mazurkiewicz J., Marczuk A.,Pochwatka P., Kujawa S. 2019. Maize Straw as a Valuable Energetic Material for Biogas Plant Feeding. Materials 12, 3848; doi: 10.3390/ma12233848

20. Moustakas K., Loizidou M. 2018. Sustainable waste management. Environmental Science and Pollution Research 25, 35761-35763. https://doi.org/10.1007/ s11356-018-3548-z

21. Mustafa M.Y., Calay R.K., Román E. 2016. Biogas from Organic Waste - A Case Study. Procedia Engineering 146, 310-317. https://doi.org/10.1016/j. proeng.2016.06.397

22. Manju Soniya S., Senophiyah-Mary J. 2020. An Experimental Study on the Generation of Biogas Using Food Waste and Water Hyacinth. In: Ghosh S. (eds) Energy Recovery Processes from Wastes. Springer, Singapore.

23. Nalepa, K., Neugebauer, M., Sołowiej, P. 2018. Dedicated control and measurement system for bioreactors to study the composting process. E3S Web Conf., Volume 132. https://doi.org/10.1051/ e3sconf/201913201018

24. Obidziński, S., Dożyńska, M., Kowczyk-Sadowy, M., Jadwisienczak, K., Sobczak, P. 2019. Densification and fuelproperties of onionhusks. Energies 12, 4687. doi:10.3390/en12244687

25. Piotrowska-Cyplik A., Chrzanowski Ł., Cyplik P., Dach J., Olejnik A., Staninska J., Czarny J.,. Lewicki A, Marecik R., Powierska-Czarny J. 2013. Composting of oiled bleaching earth: Fatty acids degradation, phytotoxicity and mutagenicity changes. International Biodeterioration \& Biodegradation 78, 49-57.

26. Robles-Aguilar A.A., Temperton V.M., Jablonowski N.D. 2019. Maize Silage Digestate Application Affecting Germination and Early Growth of Maize Modulated by Soil Type. Agronomy, 9(8), 473; https://doi.org/10.3390/agronomy9080473.

27. Wandera S. M., Qiao Wei, Algapani D. E., Shaojie Bi, Dongmin Yin, Xiangyang Qi, Yueling Liu, Dach J., Dong R. 2018. Searching for possibilities to improve the performance of full scale agricultural biogas plants. Renewable Energy 116(A), 720-727.

28. Wolna-Maruwka A., Dach J. 2009. Effect of Type and Proportion of Different Structure-Creating Additions on the Inactivation Rate of Pathogenic Bacteria in Sewage Sludge Composting in a Cybernetic Bioreactor. Archives of Environmental Protection 35 (3), 87-100.

29. Żukowska, G.Z., Mazurkiewicz, J., Myszura, M., Czekała, W. 2019. Heat Energy and Gas Emissions during Composting of Sewage Sludge. Energies, MDPI, 12(24):4782; DOI: 10.3390/ en12244782 